\title{
Quantification of Zoonotic Bacterial Pathogens within Commercial Poultry Processing Water Samples Using Droplet Digital PCR
}

\author{
Michael J. Rothrock Jr. ${ }^{*}$, Kelli L. Hiett ${ }^{2}$, Brian H. Kiepper ${ }^{3}$, Kim Ingram ${ }^{1}$, Arthur Hinton ${ }^{1}$ \\ ${ }^{1}$ Poultry Processing and Swine Physiology Research Unit, USDA-Agricultural Research Service, Athens, Georgia \\ ${ }^{2}$ Poultry Microbiological Safety Research Unit, USDA-Agricultural Research Service, Athens, Georgia \\ ${ }^{3}$ Department of Poultry Science, University of Georgia, Athens, Georgia \\ Email: *michael.rothrock@ars.usda.gov
}

Received June 21, 2013; revised July 20, 2013; accepted July 31, 2013

Copyright (C) 2013 Michael J. Rothrock Jr. et al. This is an open access article distributed under the Creative Commons Attribution License, which permits unrestricted use, distribution, and reproduction in any medium, provided the original work is properly cited.

\begin{abstract}
Raw poultry and poultry products are a significant source of zoonotic bacterial pathogen transmission; thus the sensitive detection of major zoonotic pathogens (Salmonella spp., Campylobacter jejuni, and Listeria monocytogenes) is a vital food safety issue. Recently, third generation PCR technology, known as droplet digital PCR (ddPCR) has been developed to be more accurate and sensitive to detect genetic targets than current quantification methods, but this technology has not been tested within an industrial setting. There is an on-going study within our laboratory is investigating the effects of sampling times and sampling methods on the cultural and molecular (via qPCR) quantification of dominant zoonotic pathogens within a poultry processing facility. This presents a unique opportunity to compare the quantification resulted from this emerging, third generation technology to traditional quantification methods currently employed by the poultry industry. The results show that ddPCR detected pathogen-specific genes from more pathogen:sampling time combinations than either the qPCR or culturing methods from the final scalder and chiller tanks at three stages of processing (Start, Mid, and End). In fact, both ddPCR and qPCR substantially outperformed culture methods commonly used in poultry processing food safety-related studies, with Salmonella recovered only from the Mid and End sampling times from the scalder tank. While neither C. jejuni nor L. monocytogenes were recovered culturally, ddPCR was able to detect their respective genes commonly throughout the processing day in both the scalder and chiller water samples. Additionally, the use of unfiltered processing water provided significantly greater detection of bacterial and pathogen-specific gene abundances than did an analysis of larger volumes of filtered water. Considering the ddPCR-derived concentrations of the bacterial pathogens were consistent with what was previously found culturally in commercial poultry processing operations, ddPCR represented a significant advancement in poultry processing zoonotic pathogen quantification.
\end{abstract}

Keywords: ddPCR; Poultry Processing; Zoonotic Pathogens; qPCR

\section{Introduction}

The handling and consumption of poultry or poultry products have been repeatedly associated with the transmission of bacterial pathogens to the human population. Incidences of zoonoses originating from poultry products and processing environments have been reported for Salmonella spp. [1-3], Campylobacter jejuni [4,5], and Listeria monocytogenes [6,7]. Considering the high environmental, economic, and public health costs of these zoonoses, a comprehensive understanding of the poultry production and processing parameters that allow for the

"Corresponding author. survival/transmission of these bacterial pathogens is essential.

To assess pathogen survival and transmission, accurate, sensitive, and highly specific quantification methods are needed. Historically, the quantification of foodborne pathogens in food production systems was based either on cultures or quantitative PCR (qPCR). While these methods have been used successfully, both come with caveats; either being time consuming and too ineffectively selective (culture-based) or dependent upon the proper standards and assay efficiencies (qPCR-based). To circumvent these issues, third generation PCR technology, known as droplet digital PCR (ddPCR) was introduced 
to provide absolute quantification of target genes and the pathogens to possess those genes $[8,9]$. The advantages of ddPCR over qPCR-based assays are threefold: ddPCR is based on endpoint PCR (efficiency of primer/probe annealing is minimized); ddPCR does not require the use of standards for accurate quantification; and most importantly, ddPCR is a high throughput $(15,000-20,000$ PCR reactions per well) assay.

While ddPCR represents the newest quantification technology, only relatively pure bacterial or cell culture samples have been analyzed $[9,10]$. To our knowledge, this emerging third generation PCR technology has not been applied to complex environmental samples containing mixed microbial populations, as well as organic/inorganic particulates/contaminants. Considering zoonotic foodborne pathogens can be detected in poultry carcasses but many times not within the limited sample volumes from the high capacity processing water tanks, the goal of this study is to determine the utility of ddPCR for the detection of Salmonella spp., C. jejuni, and L. monocytogenes from the commercial poultry processing tank waters, and compare these results to common pathogen detection assays (cultural, qPCR). Water from the final scalder and chiller tanks in a commercial poultry processing facility was sampled at three time points during the processing day (prior to the introduction of the first carcasses, halfway through the day, and after the last carcasses leave the tank) over three consecutive days. Additionally, the effect of water sampling method (raw water versus filtered samples) on-molecular-based detection efficacy was also determined.

\section{Materials and Methods}

\subsection{Sample Collection}

Processing water samples were collected from a commercial broiler processing facility. Small ( $\sim 4.40$ pounds) $\mathrm{Cobb}^{\circledR}$ broilers were processed at an average line speed of 364 birds per minute for $18 \mathrm{hr}$ each day. For scalder water samples, 3 sterile 1-L plastic Nalgene ${ }^{\circledR}$ bottles (Fisher Scientific, Pittsburgh, PA) were used to collect 3 $\mathrm{L}$ of water from $\sim 5 \mathrm{~cm}$ below the surface at the turnaround (midpoint) of the final scalder tank of a triple tank counterflow system. For chiller water samples, sterile 1-L Tri-pour beakers (Fisher Sci.) were placed in the basket end of a metal pole to retrieve $4 \mathrm{~L}$ of water from the posterior end of the counterflow chiller tank. In total, 3 sterile 1-L plastic Nalgene ${ }^{\circledR}$ bottles and 1 sterile 1-L glass Mason jar (for Oil and Grease content analysis; see below) were used to collect these samples. Samples were collected from these two tanks at three times during the processing shift: 1) prior to the first birds entering the cleaned and disinfected tanks (Start);2) after 9 hours ( $\sim$ half of the processing day) of processing (Mid); and, 3) after the last birds left the tank and the waters were considered "dirtiest" (End). Samples were taken from these three time points on three successive days, and were placed on ice for transport back to the laboratory for further sample processing and preparation.

\subsection{Cultural Procedures}

Nalgene ${ }^{\circledR}$ bottles were vigorously shaken to homogenize samples, and $2-100 \mathrm{~mL}$ subsamples were placed into sterile 250-mL Corning Media Bottles (Fisher Sci.). The enumeration and isolation protocols were performed as previously described for each foodborne pathogen of interest: most probable number (MPN) analysis for Salmonella spp. (Cason and Hinton, 2006); direct plate counting for $C$. jejuni using the CEFEX [11] and CampyCheck (Lastovica and Le Roux, 2001) methods; MPN and direct plate counting for L. monocytogenes (Donnelly et al., 1992).

\subsection{DNA Extraction and qPCR}

Molecular quantification was applied to raw water taken directly from the initial water samples and from the filtrate recovered from the filtration of the processing water samples. For the raw samples, DNA was extracted from two $0.5 \mathrm{~mL}$ aliquots using the FastDNA Spin Kit for Feces according to manufacturer's specifications (MP Bio, Solon, $\mathrm{OH})$. For the filtrate samples, sterile pre-moistened (in 1X PBS) cheesecloth was used to initially filter $100 \mathrm{~mL}$ of the homogenized processing water samples into a fresh 1-L Tri-pour beaker. The cheesecloth was rinsed in $20 \mathrm{~mL}$ of $1 \mathrm{X}$ PBS and the resultant filtrate was divided into $3-40 \mathrm{~mL}$ subsamples and filtered simultaneously through 3 separate $0.8 \mu \mathrm{m}$ Nalgene filter units (Fisher Sci.). The three filtrate samples were combined in 1 sterile $250-\mathrm{mL}$ centrifuge bottle (Beckman Coulter), and the cells were pelleted at $10000 \mathrm{rpm}$ for $20 \mathrm{~min}$ at $4^{\circ} \mathrm{C}$. The pellet was re-suspended in $2 \mathrm{~mL}$ of $1 \mathrm{X}$ PBS and DNA was extracted from four $0.5 \mathrm{~mL}$ aliquots using the FastDNA Spin Kit for Feces (MPBio). For both the raw and filtrate samples, all individual DNA extracts were dry-pelleted using a Vacufuge ${ }^{\mathrm{TM}}$ Plus (Eppendorf, Hauppage NY), and all extracts coming from a single sample were combined in $100 \mu \mathrm{L}$ sterile molecular grade water. The DNA concentration in each sample was determined spectrophotometrically using the Take ${ }^{\circledR}$ plate with the Synergy H4 multimode plate reader (BioTek, Winooski, VT).

All DNA extracts were diluted in sterile molecular biology grade water (5 Prime, Inc., Gaithersburg, MD) so that $10-15 \mathrm{ng}$ of genomic extract DNA was added to each qPCR reaction. All qPCRs were performed on the RealPlex 4S system (Eppendorf) in a total volume of 25 $\mu \mathrm{L}$ using the PerfeCta ${ }^{\circledR}$ qPCR Supermix (Quanta Bio- 
sciences, Gaithersburg, MD) following the previously published thermocycling conditions and final primer/ probe concentrations (Table 1).

\section{4. ddPCR DNA Amplification and Quantification}

Droplet digital PCR was performed as previously described [10] using the Bio-Rad QX100 system (Bio-Rad, Hercules, CA). In short, 1:10 dilutions of the DNA extracts were used as templates for general or pathogenspecific PCR assays using primer/probe sets listed in Table 1. TaqMan-based PCR reaction mixtures (composed of 2X ddPCR MasterMix (Bio-Rad), $900 \mathrm{nM}$ primers, $250 \mathrm{nM}$ probe, 10 - $15 \mathrm{ng}$ template DNA in a final volume of $20 \mu \mathrm{L}$ ) were mixed with droplet generation oil (Bio-Rad) and loaded into an 8-channel disposable droplet generator cartridge (Bio-Rad). The cartridge was placed into the droplet generator (Bio-Rad) to create the 20,000 droplets, which were collected from the droplet well of the cartridge and manually transferred to a 96-well PCR plate. The plate, after heat-sealing, was placed on a conventional thermal cycler (S1000; Bio-Rad) and amplified to end-point (40 cycles for all reactions). Upon completion, the 96-well plate was transferred to the droplet reader (Bio-Rad), and the droplets were automatically scanned from each well at a rate of $\sim 32$ wells/hr. Analysis of the ddPCR data was performed with the QuantaSoft analysis software package (Bio-Rad).

\subsection{Processing Water Analyses}

Poultry processing water samples were analyzed using the appropriate Standard Method [12] for COD (chemical oxygen demand method 5220D), O \& G (oil and grease method 5520D), TS (total solids method 2540B), TSS (total suspended solids method 2540D), and TKN (total Kjeldahl nitrogen method $4500-\mathrm{N}_{\text {org }} \mathrm{C}$ and $4500-\mathrm{NH}_{3} \mathrm{C}$ ). The concentration $(\mathrm{mg} / \mathrm{L})$ results from the final scalder and chiller tank processing water samples from all time points throughout the study are shown in Tables 2 and 3, respectively.

\subsection{Statistical Analyses}

Prior to analysis, all quantification (cultural and molecular) data was $\log _{10}$-transformed to ensure the data was normally distributed. Prism 6.0b (GraphPad Software Inc., La Jolla, CA) was used to perform all regression analyses, means comparisons ( $t$-tests), and ANOVAs on the microbiological data. For one-way ANOVAs, Tukey's post-tests were used to determine significant differences between pair-wise combinations. An alpha level of 0.05 was used to determine significance in all analyses.

Table 1. ddPCR and qPCR primers and probe information for this study.

\begin{tabular}{|c|c|c|c|c|c|c|c|c|}
\hline \multicolumn{2}{|l|}{ Target } & \multicolumn{2}{|r|}{ Oligo } & \multicolumn{2}{|c|}{$\begin{array}{l}\text { Final PCR mastermix } \\
\text { concentration }(\mathrm{nM})\end{array}$} & \multicolumn{2}{|c|}{$\operatorname{Tm}\left({ }^{\circ} \mathrm{C}\right)$} & \multirow[t]{2}{*}{ Reference } \\
\hline \multirow[t]{2}{*}{ Group } & \multirow[t]{2}{*}{ Gene } & Name & Sequence $\left(5^{\prime}-3^{\prime}\right)$ & $\mathrm{qPCR}$ & ddPCR & $\mathrm{qPCI}$ & dPCR & \\
\hline & & $1055 \mathrm{~F}$ & ATG GCT GTC GTC AGC T & 600 & 500 & 58 & 60 & \multirow{3}{*}{$\begin{array}{c}\text { (Harms } \\
\text { et al. 2003) } \\
{[28]}\end{array}$} \\
\hline \multirow[t]{3}{*}{ All Bacteria } & \multirow[t]{2}{*}{$16 \mathrm{~S}$} & $1392 \mathrm{R}$ & ACG GGC GGT GTG TAC & 600 & 500 & & & \\
\hline & & 16STaq1115-BHQ & FAM-CAA CGA GCG-ZEN-CAA CCC-3IABkFQ & 200 & 250 & & & \\
\hline & \multirow{3}{*}{$\operatorname{ttr}$} & Sal TTR-6-F & CTC ACC AGG AGA TTA CAA CAT GG & 400 & 500 & 65 & 60 & \multirow{3}{*}{$\begin{array}{c}\text { (Malorny } \\
\text { et al. 2004) } \\
{[29]}\end{array}$} \\
\hline \multirow[t]{2}{*}{ Salmonella spp. } & & Sal TTR-4-R & AGC TCA GAC CAA AAG TGA CCA TC & 400 & 500 & & & \\
\hline & & Sal TTR-5 ZEN & $\begin{array}{l}\text { FAM-CAC CGA CGG-ZEN-CGA GAC CGA CTT T } \\
\text {-3IABkFQ }\end{array}$ & 250 & 250 & & & \\
\hline \multirow{3}{*}{$\begin{array}{l}\text { Campylobacter } \\
\text { jejuni }\end{array}$} & \multirow{3}{*}{ hipO } & hipO-Cj-F & TCC AAA ATC CTC ACT TGC CAT T & 500 & 500 & 60 & 60 & \multirow{3}{*}{$\begin{array}{l}\text { (He et al. } \\
\text { 2010) [30] }\end{array}$} \\
\hline & & hipO-Cj-R & TGC ACC AGT GAC TAT GAA TAA CGA & 500 & 500 & & & \\
\hline & & hipO-Cj-P & $\begin{array}{c}\text { FAM-TTG CAA CCT CAC TAG CAA AAT CCA } \\
\text { CAG CT-BHQ-1 }\end{array}$ & 250 & 250 & & & \\
\hline \multirow{3}{*}{$\begin{array}{l}\text { Listeria } \\
\text { monocytogenes }\end{array}$} & \multirow{3}{*}{ hlyA } & hlyA-LisM-F & ACT GAA GCA AAG GAT GCA TCT G & 600 & 500 & 60 & 60 & \multirow{3}{*}{$\begin{array}{l}\text { (Suo et al. } \\
\text { 2010) [31] }\end{array}$} \\
\hline & & hlyA-LisM-R & TTT TCG ATT GGC GTC TTA GGA & 600 & 500 & & & \\
\hline & & hlyA-LisM-P & $\begin{array}{c}\text { FAM-CAC CAC CAG CAT CTC CGC CTG C } \\
\text {-BHQ-1 }\end{array}$ & 200 & 250 & & & \\
\hline
\end{tabular}


Table 2. Final scalder tank processing water analyses at 3 times (Start, Mid, and End) during the processing shift ${ }^{1}$.

\begin{tabular}{|c|c|c|c|c|c|c|c|c|c|c|c|c|c|c|c|c|}
\hline & \multicolumn{4}{|c|}{$\mathrm{COD}(\mathrm{mg} / \mathrm{L})$} & \multicolumn{4}{|c|}{$\mathrm{BOD}(\mathrm{mg} / \mathrm{L})^{2}$} & \multicolumn{4}{|c|}{$\mathrm{TS}(\mathrm{mg} / \mathrm{L})$} & \multicolumn{4}{|c|}{$\mathrm{TSS}(\mathrm{mg} / \mathrm{L})$} \\
\hline & Start & Mid & End & $p$-value & Start & Mid & End & $p$-value & Start & Mid & End & $p$-value & Start & Mid & End & $p$-value \\
\hline Day 1 & 0 & 1723 & 2546 & & 0 & 1014 & 1498 & & 177 & 1443 & 2176 & & 2 & 775 & 1150 & \\
\hline Day 2 & 7 & 1364 & 1375 & & 4 & 802 & 809 & & 89 & 1013 & 1000 & & 17 & 640 & 640 & \\
\hline Day 3 & 3 & 2457 & 1833 & & 2 & 1445 & 1078 & & 116 & 1946 & 1559 & & 4 & 1090 & 780 & \\
\hline Mean $^{3}$ & $3^{b}$ & $1848^{\mathrm{a}}$ & $1918^{\mathrm{a}}$ & 0.0039 & $2^{b}$ & $1087^{\mathrm{a}}$ & $1128^{\mathrm{a}}$ & 0.0039 & $127^{b}$ & $1467^{\mathrm{a}}$ & $1578^{\mathrm{a}}$ & 0.0113 & $8^{b}$ & $835^{a}$ & $857^{\mathrm{a}}$ & 0.0033 \\
\hline
\end{tabular}

${ }^{1} \mathrm{COD}=$ Chemical Oxygen Demand, BOD $=$ Biological Oxygen Demand, TS $=$ Total Solids, TSS $=$ Total Suspended Solids; ${ }^{2}$ BOD was estimated from calculated COD values using a 1.7:1.0 COD:BOD ratio that is consistent for the commercial processing plant from which these samples were collected (according to plant's environmental quality manager); ${ }^{3}$ Superscript letters $(\mathrm{a}, \mathrm{b}, \mathrm{c})$ indicate group mean separation from one-way ANOVA, based on the Tukey's post-test.

Table 3. Chiller tank processing water analyses at 3 times (Start, Mid, and End) during the processing shift ${ }^{1}$.

\begin{tabular}{|c|c|c|c|c|c|c|c|c|c|c|c|c|}
\hline & \multicolumn{4}{|c|}{$\mathrm{COD}(\mathrm{mg} / \mathrm{L})$} & \multicolumn{4}{|c|}{$\mathrm{BOD}(\mathrm{mg} / \mathrm{L})^{2}$} & \multicolumn{4}{|c|}{$\mathrm{TS}(\mathrm{mg} / \mathrm{L})$} \\
\hline & Start & Mid & End & $p$-value & Start & Mid & End & $p$-value & Start & Mid & End & $p$-value \\
\hline Day1 & 0 & 1478 & 2609 & & 0 & 869 & 1535 & & 195 & 646 & 1440 & \\
\hline Day2 & 82 & 1207 & 2144 & & 48 & 710 & 1261 & & 133 & 1294 & 1949 & \\
\hline Day3 & 60 & 1346 & 2367 & & 35 & 792 & 1392 & & 348 & 1433 & 2176 & \\
\hline \multirow[t]{3}{*}{ Mean $^{3}$} & $47^{\mathrm{c}}$ & $1344^{b}$ & $2373^{\mathrm{a}}$ & $<0.0001$ & $28^{b}$ & $790^{\mathrm{a}}$ & $1396^{a}$ & $<0.0001$ & $225^{b}$ & $1124^{\mathrm{a}}$ & $1855^{\mathrm{a}}$ & 0.0029 \\
\hline & \multicolumn{4}{|c|}{$\mathrm{TSS}(\mathrm{mg} / \mathrm{L})$} & \multicolumn{4}{|c|}{ TKN (mg/L) } & \multicolumn{4}{|c|}{ Oil \& Grease $(\mathrm{mg} / \mathrm{L})^{1}$} \\
\hline & Start & Mid & End & $p$-value & Start & Mid & End & $p$-value & Start & Mid & End & $p$-value \\
\hline Day1 & 2 & 350 & 550 & & 0 & 114 & 97.2 & & 0 & 76.2 & 119 & \\
\hline Day2 & 18 & 275 & 595 & & 1.01 & 81 & 114 & & 14 & 66.4 & 125 & \\
\hline Day3 & 16 & 268 & 478 & & 1.27 & 91.8 & 137 & & 7 & 96.2 & 192 & \\
\hline Mean $^{3}$ & $12^{\mathrm{c}}$ & $298^{b}$ & $541^{\mathrm{a}}$ & 0.0001 & $0.76^{\mathrm{b}}$ & $95.6^{\mathrm{a}}$ & $116.1^{a}$ & 0.0002 & $7.0^{c}$ & $79.6^{\mathrm{b}}$ & $145.3^{\mathrm{a}}$ & 0.0016 \\
\hline
\end{tabular}

${ }^{1} \mathrm{COD}=$ Chemical Oxygen Demand, BOD = Biological Oxygen Demand, TS = Total Solids, TSS = Total Suspended Solids, TKN $=$ Total Kjeldahl Nitrogen; ${ }^{2} \mathrm{BOD}$ was estimated from calculated COD values using a 1.7:1.0 COD:BOD ratio that is consistent for the commercial processing plant from which these samples were collected (according to plant's environmental quality manager); ${ }^{3}$ Superscript letters (a, b, c) indicate group mean separation from one-way ANOVA, based on the Tukey's post-test.

\section{Results and Discussion}

\subsection{Commercial Poultry Processing Water Analyses}

All processing water characteristics significantly increased after the beginning of the processing day for the final scalder (Table 2) and chiller (Table 3) tanks. This was expected since a variety of organics/particulates are introduced into these water tanks throughout the processing day from the carcasses. All measured final scalder water samples reached a plateau value by the Mid sampling time that did not significantly change by the End sampling (Table 2). Conversely, only 2 of the tested variables in the chiller tank (TS and TKN) reached this plateau, with all other variables significantly increasing throughout the sampling day (Table 3). These values are consistent with previous scalder and chiller tank assessments from within commercial processing facilities [13, $14]$, indicating that this study was run under normal in- dustry conditions.

\subsection{Comparison of Processing Water Sampling Techniques}

Considering commercial poultry processing waters contain a variety of organic particulates (e.g. blood, feathers, oils/fats), two different water sampling methods were assessed for molecular analyses: 1) analysis of $1 \mathrm{~mL}$ of raw water sample, or 2) filtering $100 \mathrm{~mL}$ of processing water through a $0.8 \mu \mathrm{M}$ filter (to remove particulates) and analyzing that cells in the filtrate. When looking at 16S rRNA gene copies (a molecular estimate of total bacteria) in these processing water samples, significantly higher total bacterial gene copies were recovered from both scalder (Figure 1(a)) and chiller (Figure 1(b)) waters when using the $1 \mathrm{~mL}$ raw samples for both ddPCR (closed bars) and qPCR (open bars) as compared to the $100 \mathrm{~mL}$ filtrate samples. Additionally, 16S rRNA gene 


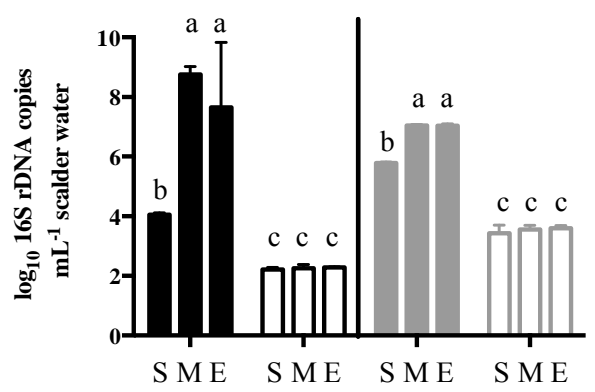

(a)

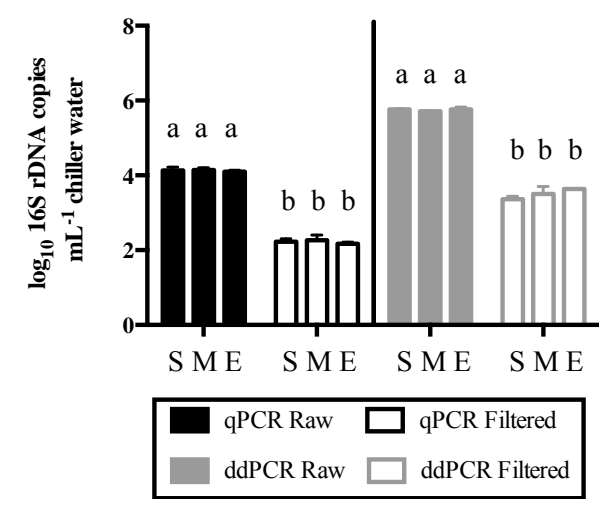

(b)

Figure 1. Comparison of total bacteria recovered molecularly (based on 16S rDNA gene copies) between sampling 1 $\mathrm{mL}$ of raw processing water or $100 \mathrm{~mL}$ of filtrate from the final scalder (a) and chiller (b) processing water samples. Samples were taken at three time points during the processing day $(S=$ Start, $M=$ Mid, $E=$ End) and pathogen concentrations were $\log _{10}$-transformed. Molecular quantification was performed using ddPCR (black) and qPCR (light gray) on both raw samples (solid bars) and filtrate samples (open bars). Bars represent the mean value for three consecutive sampling days, and the error bars represent the standard deviation, while the letters above the bars represent groups with significantly different mean pathogen concentrations (according to one-way ANOVA using Tukey's post-test).

copies significantly increased in the Mid and End sampling times in the scalder water for both the ddPCR and qPCR methods when using the $1 \mathrm{~mL}$ raw sample (Figure 1(a)). This gene abundance change within the scalder water was not observed in the $100 \mathrm{~mL}$ filtrate samples.

It has been shown that scald water, although continually recharged with fresh water, can build up a microbiota associated with carcass-associated organic contaminants (e.g. feathers, fecal material) [15], and this bacterial load can become intimately associated with this organic material. The removal of this bacterial-rich organic material during filtration could explain the significant difference in the bacterial populations between the filtrate and raw samples at the Mid and End sampling times (Figure 1). As observed in the raw scalder water samples, carcasses sampled from the middle to end of commercial poultry processing runs have shown significantly greater bacterial contamination $[16,17]$, thus supporting the use of this non-filtration based sampling technique for these processing water samples. While the qPCR data showed a much greater increase $(\sim 4 \log )$ as compared to the ddPCR method $(\sim 1 \log )$, the dynamic range of the qPCR method (up to $\sim 9 \log$ ) is much higher than that of ddPCR ( 6 log) [8-10]. Therefore, more dilute DNA extracts need to be used for highly concentrated processing water samples $\left(>10^{7}\right.$ cells $\left.\cdot \mathrm{mL}^{-1}\right)$ when using ddPCR quantification.

In terms of zoonotic bacterial pathogens, higher gene abundances were consistently detected from the $1 \mathrm{~mL}$ raw samples as compared to the $100 \mathrm{~mL}$ filtrate samples using both ddPCR and qPCR (Table 4), with raw sample values being significantly higher in $33 \%$ of the possible scalder water combinations for both ddPCR and qPCR. High levels of organic material in scalder tanks, like those observed during the Mid and End sampling times (Table 2), have allowed for the persistence and cross contamination of Salmonella and other bacterial pathogens during the scalding process $[1,18,19]$. The removal of this organic material via filtration, and the bacteria associated with this material, could explain the significantly higher bacterial pathogen detection within the raw scalder samples. In only four possible pathogen:sampling time combinations for the chiller tank water samples were the $100 \mathrm{~mL}$ filtrate values higher than the $1 \mathrm{~mL}$ raw water samples, but none were significantly higher. Considering this demonstrated enhanced detection for both total bacteria and the zoonotic bacterial pathogens, all results discussed below represent analyses of the $1 \mathrm{~mL}$ raw water samples.

\subsection{Bacterial Pathogen Detection in Commercial Poultry Processing Water Tanks}

In the final scalder tank, detectable levels of pathogenspecific genes were found using ddPCR during all three sampling times on at least one of the sampling days (Figure 2), with most being detected at least twice. Only for Salmonella spp. did the other quantification methods perform as well as ddPCR, although the cultural numbers were significantly lower than those found by both the ddPCR and qPCR methods (Figure 2(a)). The samples (prior to any carcasses being introduced into the tanks) may be due to the ability of bacterial pathogens to survive these disinfection procedures. Previous research has demonstrated that $C$. jejuni can survive on these tank surfaces after cleaning and disinfection [20].

While the use of qPCR produced statistically similar values to the ddPCR method for the scalder tank water samples (Figure 2), there were three instances ( $C$. jejuni-Start; L. monocytogenes-Start and End) where only ddPCR detected pathogen-specific genes. Cultural quantification only detected Salmonella spp. in the scalder 
Table 4. Comparison of $1 \mathrm{~mL}$ raw and $100 \mathrm{~mL}$ filtrate processing water-sampling techniques on recovered ddPCR- and qPCR-derived $\log _{10}$-transformed zoonotic pathogen concentrations ${ }^{1}$.

\begin{tabular}{|c|c|c|c|c|c|c|c|c|c|c|c|c|c|}
\hline & \multirow[b]{3}{*}{ Target $^{2}$} & \multicolumn{6}{|c|}{ ddPCR } & \multicolumn{6}{|c|}{ qPCR } \\
\hline & & \multicolumn{3}{|c|}{ Final Scalder Tank Water } & \multicolumn{3}{|c|}{ Chiller Tank Water } & \multicolumn{3}{|c|}{ Final Scalder Tank Water } & \multicolumn{3}{|c|}{ Chiller Tank Water } \\
\hline & & Sspp & $\mathrm{Cj}$ & $\mathrm{Lm}$ & Sspp & $\mathrm{Cj}$ & $\mathrm{Lm}$ & Sspp & $\mathrm{Cj}$ & $\mathrm{Lm}$ & Sspp & $\mathrm{Cj}$ & $\mathrm{Lm}$ \\
\hline \multirow{3}{*}{ Start } & Raw & 0.924 & 1.638 & 0.808 & 0.000 & 0.824 & 0.000 & 0.866 & 0.000 & 0.000 & 0.632 & 0.394 & 0.373 \\
\hline & Filtrate & 0.261 & 0.000 & 0.000 & 0.636 & 0.000 & 0.000 & 0.002 & 0.000 & 0.000 & 0.158 & 0.000 & 0.085 \\
\hline & $p$-value ${ }^{3}$ & 0.4928 & 0.0452 & 0.5135 & 0.3469 & 0.3366 & $>0.999$ & 0.0216 & $>0.999$ & $>0.999$ & 0.4658 & 0.1285 & 0.4722 \\
\hline \multirow{3}{*}{ Mid } & Raw & 2.032 & 2.731 & 0.830 & 0.000 & 0.809 & 0.823 & 2.400 & 2.639 & 0.688 & 0.038 & 0.000 & 0.689 \\
\hline & Filtrate & 0.317 & 0.147 & 0.000 & 0.000 & 0.301 & 1.508 & 0.143 & 0.000 & 0.000 & 0.000 & 0.138 & 0.000 \\
\hline & $p$-value & 0.0222 & 0.0097 & 0.5018 & $>0.999$ & 0.5487 & 0.5461 & $<0.0001$ & 0.0020 & 0.1136 & 0.9528 & 0.5773 & 0.1014 \\
\hline \multirow{3}{*}{ End } & Raw & 1.092 & 1.165 & 0.846 & 1.080 & 0.810 & 1.660 & 0.675 & 1.148 & 0.000 & 0.883 & 0.000 & 0.428 \\
\hline & Filtrate & 0.157 & 0.000 & 1.503 & 0.000 & 0.142 & 0.000 & 0.072 & 0.000 & 0.118 & 0.000 & 0.019 & 0.000 \\
\hline & $p$-value & 0.3379 & 0.1910 & 0.5937 & 0.1225 & 0.4328 & 0.1578 & 0.0905 & 0.1141 & 0.7738 & 0.1857 & 0.9389 & 0.2922 \\
\hline
\end{tabular}

${ }^{1}$ Values represent $\log _{10}$-transformed means of zoonotic pathogen-specific gene abundances from three consecutive sampling days within the commercial poultry processing plant, and the $p$-values result from one-tailed $t$-tests; ${ }^{2}$ Pathogen abbreviations are: Sspp $=$ Salmonella spp.; $C j=$ Campylobacter jejuni; Lm $=$ Listeria monocytogenes; ${ }^{3}$ Bolded values indicate significant differences between the raw and filtered samples at the $\alpha=0.05$ level.

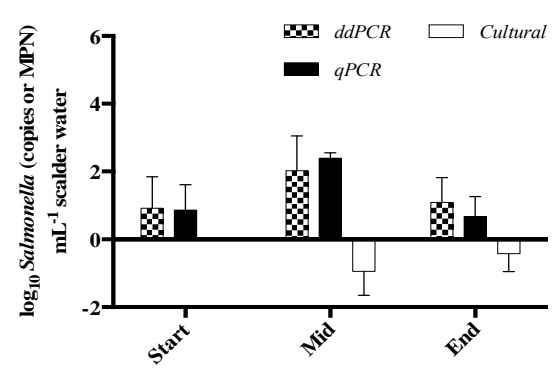

(a)

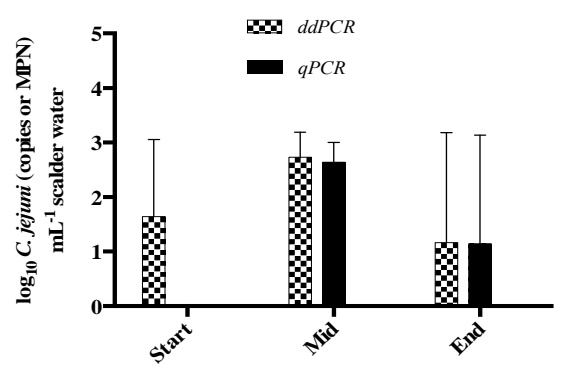

(b)

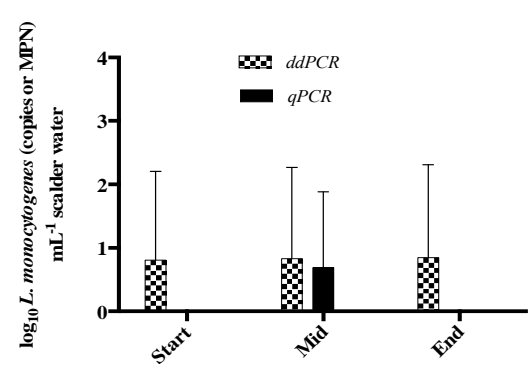

(c)

Figure 2. Quantification of zoonotic pathogens found within the final scalder tank of a commercial poultry processing facility. Samples were taken at three time points during the processing day (Start, Mid, End) and $\log _{10}$-transformed pathogen quantifications were performed using ddPCR (checkered bars), qPCR (solid bars), and cultural methods (open bars). Bars represent the mean value for three consecutive sampling days, and the error bars represent the standard deviation. Zoonotic pathogens tested for were (a) Salmonella spp.; (b) C. jejuni; and (c) L. monocytogenes.

tank in two of the three sampling days, failing to detect and recover any of the other pathogens during this study. While these pathogens have been isolated from commercial scalder tanks previously $[1,3,21,22]$, their recovery was significantly higher in the first two tanks of similar commercial triple scalder tank systems [19,23]; whereas the final scalder tank was sampled in the current study.

While there are obvious arguments about the use of cultural versus molecular detection techniques (e.g. isolating a living organism versus the DNA signature of one), the ddPCR values for Salmonella were consistent with those found culturally in previous commercial scalder tank studies [19,23]. Additionally, the ddPCR-based prevalence of $C$. jejuni and L. monocytogenes within the scalder water samples from this study were consistent with one of the few other studies to molecularly detect and culturally confirm these pathogens within a commer- cial poultry processing plant [7]. The consistency of these ddPCR results with cultural results from previous commercial processing investigations, in addition to the significantly higher detection rate compared to cultural data from this current study, indicates the efficacy of ddPCR for bacterial pathogen detection within these samples.

In the chiller water samples, Salmonella spp., C. jejuni, and L. monocytogenes specific genes were detected in the End samples using ddPCR, and all but Salmonella spp. specific genes were present in the Mid samples (Figure 3). As was observed with the scalder water samples, ddPCR was able to detect pathogen-specific genes in more possible pathogen:sampling time combinations than either comparative quantification method. Pathogen detection in these chiller water samples was more sporadic than in the scalder tank samples, with ddPCR detecting 


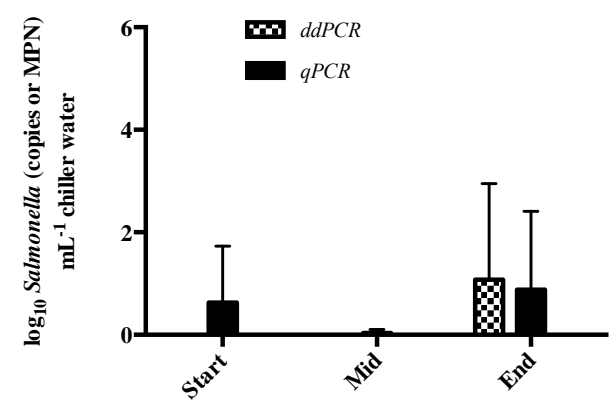

(a)

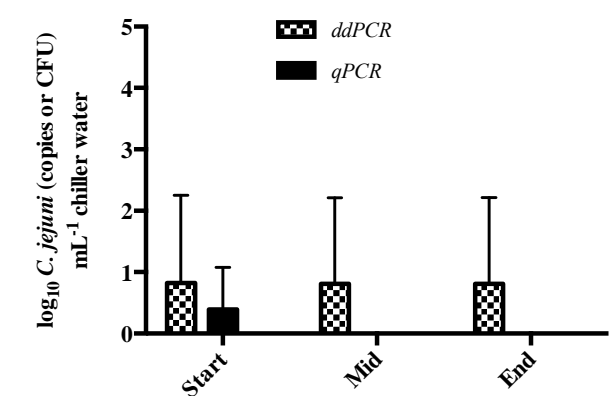

(b)

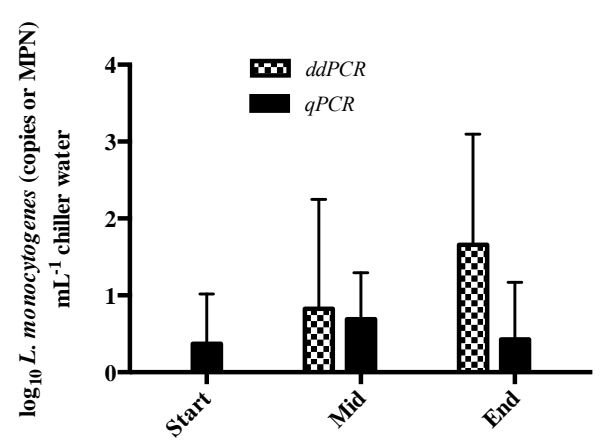

(c)

Figure 3. Quantification of zoonotic pathogens found within the chiller tank of a commercial poultry processing facility. Samples were taken at three time points during the processing day (Start, Mid, End) and $\log _{10}$-transformed pathogen quantifications were performed using ddPCR (checkered bars) and qPCR (solid bars). None of the pathogens were recovered culturally from the chiller water Bars represent the mean value for three consecutive sampling days, and the error bars represent the standard deviation. Zoonotic pathogens tested for were (a) Salmonella spp., (b) $C$. jejuni, and (c) L. monocytogenes.

these pathogens on only one of the three sampling days in most samples. Considering one of the main objectives is disinfection via chlorination in the chiller tank to reduce bacterial loads [2,3,24], the lower and less consistent detection of pathogen-specific genes in this tank versus the scalder tank samples was expected. In comparison to the qPCR-based method, ddPCR more consistently detected $C$. jejuni (Figure 3(b)) whereas qPCR more consistently detected Salmonella spp. (Figure 3(a)). The presence of each of these bacterial pathogens at some point during the processing run was surprising, but high organic matter loads (Table 3; COD, BOD) is known to reduce the bactericidal efficacy of chlorine within chiller tanks $[1,25]$

None of the bacterial pathogens were detected culturally from any of the chiller water samples. While Salmonella, C. jejuni, and L. monocytogenes have been previously recovered culturally from commercial chiller tanks $[1,2,7,21,26]$, chiller samples for this current study were retrieved from the distal end of the counterflow chiller tank (carcasses leave the tank and clean water enters the tank). This is important to note because ria, specifically Salmonella, cannot be detected using traditional culturing methods at the endpoint of the chiller tank, even if found in water samples from the proximal end of the tank [27]. It is also possible that the chlorine contained within these chiller samples confounded the cultural recovery, since its bactericidal effects potentially extended onto the selective media plates within the aliquot that was incubated. Considering the DNA extraction process claims to remove contaminants such as chlorine, and ddPCR was the most robust pathogen quantification technique in the chiller water samples, ddPCR represents a powerful new tool effectively detect and quantify zoonotic pathogens within chiller water.

\section{Conclusion}

These findings represent the first report of the use of third generation PCR technology to detect zoonotic bacterial pathogen signatures in environmental samples along the poultry production continuum. While more validation of this ddPCR method needs to be performed on more poultry-related environmental sample types, the results of this study highlight the advantages of ddPCR and the potential for the integration of this highly sensitive and specific method into future poultry food safety research. Given the much higher throughput and absolute quantification of ddPCR while producing statistically similar results to qPCR in this study, this third generation technology represents a significant improvement in the molecular detection and quantification of zoonotic pathogens in commercial industry environments. Obtaining cultural isolates is still essential within the regulatory framework of food safety research, but ddPCR represents a significant improvement in the ability to determine the presence and possible transmission of pathogen-specific genes within the poultry production environment, especially given the low infectious dose of some of these zoonotic bacterial pathogens.

\section{Acknowledgements}

The authors would like to acknowledge the expert technical assistance of Latoya Wiggins, Nicole Bartenfeld, and Kathy Tate for their assistance in sampling and cul- 
tural work, as well as John Gamble and Laura Lee Rutherford for their assistance in sampling and molecular analyses. These investigations were supported equally by the Agricultural Research Service, USDA CRIS Projects "Pathogen Reduction and Processing Parameters in Poultry Processing Systems" \#6612-41420-017-00 and "Molecular Approaches for the Characterization of Foodborne Pathogens in Poultry" \#6612-32000-059-00.

\section{REFERENCES}

[1] S. Buncic and J. Sofos, "Interventions to Control Salmonella Contamination during Poultry, Cattle and Pig Slaughter," Food Research International, Vol. 45, No. 2, 2012, pp. 641-655. doi:10.1016/j.foodres.2011.10.018

[2] J. M. Cox and A. Pavic, "Advances in Enteropathogen Control in Poultry Production," Journal of Applied Microbiology, Vol. 108, No. 3, 2010, pp. 745-755. doi:10.1111/j.1365-2672.2009.04456.x

[3] S. Finstad, C. A. O’Bryan, J. A. Marcy, P. G. Crandall and S. C. Ricke, "Salmonella and Broiler Processing in the United States: Relationship to Foodborne Salmonellosis," Food Research International, Vol. 45, No. 2, 2012 , pp. 789-794. doi:10.1016/j.foodres.2011.03.057

[4] C. R. Friedman, R. M. Hoekstra, M. Samuel, R. Marcus, J. Bender, B. Shiferaw, et al., "Risk Factors for Sporadic Campylobacter Infection in the United States: A CaseControl Study in FoodNet Sites," Clincal Infectious Disease, Vol. 38, Suppl. 3, 2004, pp. S285-S296.

[5] E. M. Nielsen, V. Fussing, J. Engberg, N. L. Nielsen and J. Neimann, "Most Campylobacter Subtypes from Sporadic Infections Can Be Found in Retail Poultry Products and Food Animals," Epidemiology \& Infection, Vol. 134, No. 4, 2006, pp. 758-767. doi:10.1017/S0950268805005509

[6] L. M. Lawrence and A. Gilmour, "Incidence of Listeria spp. and Listeria monocytogenes in Poultry Products and the Poultry Processing Environment, and Their Rapid Confirmation by Multiplex PCR," Applied Environmental Microbiology, Vol. 60, No. 12, 1994, pp. 4600-4604.

[7] M. G. R. Reiter, C. M. M. Bueno, C. Lopez and R. Jordano, "Occurrence of Campylobacter and Listeriamonocytogenes in a Poultry Processing Plant," Journal of Food Protection, Vol. 68, No. 9, 2005, pp. 1903-1906.

[8] M. Baker, "Digital PCR Hits Its Stride," Nature Methods, Vol. 9, No. 6, 2012, pp. 541-544. doi:10.1038/nmeth.2027

[9] L. B. Pinheiro, V. A. Coleman, C. M. Hindson, J. Herrmann, B. J. Hindson, S. Bhat, et al., "Evaluation of a Droplet Digital Polymerase Chain Reaction Format for DNA Copy Number Quantification," Analytical Chemistry, Vol. 84, No. 2, 2012, pp. 1003-1011. doi:10.1021/ac202578x

[10] B. J. Hindson, K. D. Ness, D. A. Masquelier, P. Belgrader, N. J. Heredia, A. J. Makarewicz, et al., "High-Throughput Droplet Digital PCR System for Absolute Quantitation of DNA Copy Number," Analytical Chemistry, Vol. 83, No. 22, 2011, pp. 8604-8610. doi:10.1021/ac202028g

[11] N. J. Stern, B. Wojton and K. Kwiatek, "A Differential-
Selective Medium and Dry Ice-Generated Atmosphere for Recovery of Campylobacterjejuni," Journal of Food Protection, Vol. 55, No. 7, 1992, pp. 514-517.

[12] APHA, "Standard Methods for the Examination of Water and Wastewater," 21st Edition, American Public Health Association, Washington DC, 2005,

[13] D. Hamm, "Characteristics of Effluents in Ten Southeastern Poultry Processing Plants," Poultry Science, Vol. 51, No. 3, 1972, pp. 825-829. doi:10.3382/ps.0510825

[14] W. C. Merka, "Processing Water and Wastewater," In: A. R. Sams, Ed., Poultry Meat Processing, CRC Press LLC, Boca Raton, 2001, pp. 301-310.

[15] F. L. Bryan and M. P. Doyle, "Health Risks and Consequences of Salmonella and Campylobacter jejuni in Raw Poultry," Journal of Food Protection, Vol. 58, No. 3, 1995, pp. 326-344.

[16] Z. Bełkot, "Bacterial Contamination of Chicken Carcasses as Influenced by the Time of Slaughter during the Day," Medycyna Weterynaryjna, Vol. 67, No. 11, 2011, pp. 760-764.

[17] P. Whyte, K. McGill, C. Monahan and J. D. Collins, "The Effect of Sampling Time on the Levels of Micro-Organisms Recovered from Broiler Carcasses in a Commercial Slaughter Plant," Food Microbiology, Vol. 21, No. 1, 2004, pp. 59-65. doi:10.1016/S0740-0020(03)00040-6

[18] M. E. Berrang, J. A. Dickens and M. T. Musgrove, "Effects of Hot Water Application after Defeathering on the Levels of Campylobacter, Coliform Bacteria, and Escherichia coli on Broiler Carcasses," Poultry Science, Vol. 79, No. 11, 2000, pp. 1689-1693.

[19] J. A. Cason and A. Hinton Jr., "Coliforms, Escherichiacoli, Campylobacter, and Salmonella in a Counterflow Poultry Scalder with a Dip Tank," International Journal of Poultry Science, Vol. 5, No. 9, 2006, pp. 846-849. doi:10.3923/ijps.2006.846.849

[20] M. B. Peyrat, C. Soumet, P. Maris and P. Sanders, "Recovery of Campylobacterjejuni from Surfaces of Poultry Slaughterhouses after Cleaning and Disinfection Procedures: Analysis of a Potential Source of Carcass Contamination," International Journal of Food Microbiology, Vol. 124, No. 2, 2008, pp. 188-194. doi:10.1016/j.ijfoodmicro.2008.03.030

[21] G. Figueroa, M. Troncoso, C. Ĺopez, P. Rivas and M. Toro, "Occurrence and Enumeration of Campylobacter spp. during the Processing of Chilean Broilers," $B M C$ Microbiology, Vol. 9, 2009, p. 94.

[22] H. Yang, Y. Li and M. G. Johnson, "Survival and Death of Salmonella typhimurium and Campylobacterjejuni in Processing Water and on Chicken Skin during Poultry Scalding and Chilling," Journal of Food Protection, Vol. 64, No. 6, 2001, pp. 770-776.

[23] J. A. Cason, A. Hinton Jr. and K. D. Ingram, "Coliform, Escherichiacoli, and Salmonellae Concentrations in a Multiple-Tank, Counterflow Poultry Scalder," Journal of Food Protection, Vol. 63, No. 9, 2000, pp. 1184-1188.

[24] J. D. Stopforth, R. O'Connor, M. Lopes, W. E. Hill and M. Samadpour, "Validation of Individual and Multiple Sequential Interventions for Reduction of Microbial Populations during Processing of Poultry Carcasses and 
Parts," Journal of Food Protection, Vol. 70, No. 6, 2007 , pp. 1393-1401.

[25] K. C. Tamblyn, D. E. Conner and S. F. Bilgili, "Utilization of the Skin Attachment Model (SAM) to Determine the Antibacterial Activity of Potential Carcass Treatments," Poultry Science, Vol. 76, No. 9, 1997, pp. 13181323.

[26] C. Voidarou, D. Vassos, T. Kegos, A. Koutsotoli, A. Tsiotsias, J. Skoufos, et al., "Aerobic and Anaerobic Microbiology of the Immersion Chilling Procedure during Poultry Processing," Poultry Science, Vol. 86, No. 6, 2007, pp. 1218-1222.

[27] J. K. Northcutt, D. Smith, R. I. Huezo and K. D. Ingram, "Microbiology of Broiler Carcasses and Chemistry of Chiller Water as Affected by Water Reuse," Poultry Science, Vol. 87, No. 7, 2008, pp. 1458-1463. doi: $10.3382 /$ ps.2007-00480

[28] G. Harms, A. C. Layton, H. M. Dionisi, I. R. Gregory, V. M. Garrett, S. A. Hawkins, et al., "Real-Time PCR Quantification of Nitrifying Bacteria in a Municipal Wastewa- ter Treatment Plant," Environmental Science and Technology, Vol. 37, No. 2, 2003, pp. 343-351. doi:10.1021/es0257164

[29] B. Malorny, E. Paccassoni, P. Fach, C. Bunge, A. Martin and R. Helmuth, "Diagnostic Real-Time PCR for Detection of Salmonella in Food," Applied Environmental Microbiology, Vol. 70, No. 12, 2004, pp. 7046-7052. doi:10.1128/AEM.70.12.7046-7052.2004

[30] Y. He, X. Yao, N. W. Gunther IV, Y. Xie, S.-I. Tu and X. Shi, "Simultaneous Detection and Differentiation of Campylobacter jejuni, C. coli, and C. lari in Chickens Using a Multiplex Real-Time PCR Assay," Food Analytical Methods, Vol. 3, No. 4, 2010, pp. 321-329.

[31] B. Suo, Y. He, S.-I. Tu and X. Shi, "A Multiplex RealTime Polymerase Chain Reaction for Simultaneous Detection of Salmonells spp., Escherichia coli O157, and Listeria monocytogenes in Meat Products," Foodborne Pathogens \& Disease, Vol. 7, No. 6, 2010, pp. 619-628. doi:10.1089/fpd.2009.0430 